\title{
ANTICUERPOS CONTRA EL VIRUS DE LA DIARREA VIRAL BOVINA EN MUESTRAS DE LECHE DE BOVINOS DEL VALLE DEL MANTARO (JAUJA, CONCEPCIÓN Y HUANCAYO)
}

\author{
George Contreras N. ${ }^{1}$, Karl Stahl ${ }^{1}$, Carlos Arana D. ${ }^{2}$ y Hermelinda \\ Rivera G. 3
}

\section{Abrtact}

The prevalence of bovine viral diarrhea (BVDV) using milk samples of dairy cows of The Mantaro Valley, Junin was determined. Milk $(n=228)$ and blood samples $(n=65)$ were taken from cows from 18 herds for detection of antibodies against BVDV by an indirect ELISA and neutralisation tests. The prevalence of BVDV was $72.4 \%(165 / 228)$. The optical densities of the samples ranged fron 0 to 2.4. All the herds sampled contained reactors to BVDV with prevalence between 9.4 to $100 \%$. The high prevalence of BVDV confirms its wide distribution in dairy herds in The Mantaro Valley. The concordance high between the indirect ELISA and virus neutralisation tests for detecting antibodies against BVDV in milk and serum samples respectively, indicate that the indirect ELISA in milk samples could replace the virus neutralisation test for epidemiological studies on BVD.

Key words: Bovine, bovine viral diarrhoea virus, milk, serum, antibodies, indirect ELISA.

\section{Resumen}

Se determinó la prevalencia del virus de la diarrea viral bovina (VDVB) en muestras de leche de bovinos de las tres provincias ubicado en el Valle del Mantaro, Junín. Con este propósito se colectaron muestras de leche $(228)$ y sangre $(n=65)$ de vacas en producción de 18 hatos lecheros para la detección de anticuerpos contra el VDVB mediante una prueba de ELISA indirecta y virus neutralización. El 72.4\% (165/228) de los animales muestreados presentaron anticuerpos contra el virus en leche. La prevalencia del VDVB fue mayor en los animales de las provincias de Concepción (86.3\%), seguido por Jauja (83.3\%) y Huancayo (41.3\%). Las densidades opticas corregidas de las muestras fluctuaron entre 0 a 2.4 . EI VDVB fue detectado en todos los hatos muestreados en rangos de 9.4 a $100 \%$. La alta prevalencia del VDVB en los animales de todos los hatos muestreados confirma la amplia difusión del virus en la población bovina del Valle del Mantaro. Las pruebas de ELISA indirecta y virus neutralización tuvieron una perfecta concordancia al obtenerse similares resultados en 65 muestras de leche pareado con el suero de las vacas por lo que se recomienda el uso de la prueba de ELISA indirecta en muestras de leche para el estudio de DVB y otras enfermedades prevalentes en el Valle del Mantaro.

Palabras claves: Bovinos, virus de la diarrea viral bovina, leche, anticuerpos, ELISA indirecta. 


\section{mringentin}

La diarrea viral bovina (DVB) es una enfermedad de impacto económico que afecta a los rumiantes domésticos y salvajes a nivel mundial (Houe 1995). Puede ser transmitida al animal susceptible por inhalación o ingestión de secreción ocular y/o nasal, salival, uterina, heces, placenta y semen de animales con infección aguda o subclínica (Houe, 1995).

El agente causal es el virus de la diarrea viral bovina (VDVB), un miembro del género pestivirus, familia Flaviviridae (Wengler et al., 1995). El virus posee un especial tropismo por las células del sistema inmune y células epiteliales de los tractos reproductivo, entérico y respiratorio (Marshall et al., 1994) ocasionando como consecuencia de su replicación en estas células, un conjunto de patologías no observado en otros agentes infecciosos ( $\mathrm{Li}$ et al., 1998; Schreiber et al., 1999).

Una de las características de los pestivirus como el VDVB, es que las cepas pueden ser de dos biotipos: citopatogénicos (CP) y no citopatogénicos (NCP) basado sólo en su característica de cultivo in vitro. En el animal ambos biotipos producen la enfermedad. Las cepas NCP del VDVB son las más comúnmente aisladas de los casos del campo y los reservorios de estas cepas son los animales persistentemente infectados (Bezek, 1995). Los animales con infección persistente surgen únicamente como consecuencia de la infección de la vaca con la cepa NCP durante el primer tercio de la gestación (Brownlie et al., 1998; Fredriksen et al., 1999). Estos animales son difíciles de reconocer y pueden alcanzar la etapa reproductiva y transmitir el virus a sus crías perpetuando el virus en el hato (Bezek, 1995). Además, los animales con infección persistente pueden desarrollar una forma aguda y mortal de DVB conocida como Enfermedad de las Mucosas si son superinfectados con una cepa del VDVB CP (Fritzemeier et al., 1997).

El VDVB causa una marcada inmunodepresión en el bovino, la cual favorece la prevalencia y severidad del complejo respiratorio bovino especialmente por el virus de la rinotraqueítis infecciosa bovina, virus respiratorio sicitial o Pasteurella haemolitica sobre todo en el animal joven y en los animales de los centros de engorde a nivel mundial (Potgieter, 1997; Rivera $e t$ al., 1994) ocasionando cuantiosas pérdidas económicas. Asimismo, existen evidencias de que el VDVB es uno de los agentes causantes de fallas reproductivas en bovinos lecheros del valle de Lima (Rivera $e t$ al., 1993)

Estudios serológicos realizados en bovinos de las principales cuencas lecheras del Perú demuestran que el VDVB está ampliamente difundido, alcanzando prevalencias superiores al 50\% (Rivera $\mathrm{H}$. datos no publicados); sin embargo, se dispone de escasa información de su prevalencia en bovinos lecheros de los valles interandinos y bovinos criollos de la sierra. Uno de los valles con gran potencial para la cría de ganado lechero es el Valle del Mantaro en Huancayo (Junín) donde la crianza bovina está en manos de pequeños productores con un promedio 2 a 3 vacas en ordeño, con una producción de $7.21 /$ vaca/día (Fernández Baca y Bojórquez, 1995). Informaciones recogidas de los productores del valle durante una rápida encuesta manifestaron que los principales problemas sanitarios en sus hatos fueron los problemas respiratorios, diarreicos en terneros y abortos, por lo que el presente trabajo tuvo como objetivo determinar la prevalencia del VDVB en muestras de leche en lugar del suero de bovinos del Valle del 
Mantaro y contribuir a un mejor conocimiento de la epidemiología de la DVB en el país.

\section{Materal y Metodos}

\section{Animales y muestras}

El estudio fue realizado en bovinos lecheros de 18 hatos distribuidos en las provincias de Jauja, Concepción y Huancayo. El tamaño muestral ( $n=228$ ) se obtuvo mediante el método para estimar una proporción a través de la aproximación normal a la distribución normal,utilizándo para su cálculo una proporción de 0.89 (Rivera, H. comunicación personal) y un nivel de confianza del $95 \%$. Además se obtuvieron 65 muestras de suero de las mismas vacas en los hatos donde el dueño lo permitió.

Las muestras de leche y sangre fueron obtenidas individualmente durante el ordeño y transportadas al Laboratorio de Microbiología del IVITA - El Mantaro, de la Facultad de Medicina Veterinaria (FMV) de la Universidad Nacional Mayor de San Marcos (UNMSM) para el procesamiento del descremado en caso de la leche y obtención del suero sanguíneo. Las muestras procesadas fueron colocados en viales y transportadas al Laboratorio de Virología de la FMV, UNMSM donde fueron congeladas a $-20^{\circ} \mathrm{C}$ hasta su procesamiento.

\section{Reactivos}

Se utilizaron Kits de ELISA indirecta (Svanovir, Suecia) para muestras de leche, donados por la Universidad Agrícola de Upsala, Suecia a la FMV, UNMSM. Cada kit consistió en microplacas de 96 hoyos cubiertos con antígeno del VDVB, anti-IgG bovino conjugado con peroxidasa, mues- tras de leche de referencia positivo y negativo y otros reactivos utilizados en la prueba de ELISA.

Cultivos celulares secundarios de cornete nasal de feto bovino, preparados en el Laboratorio de Virología de la FMV, UNMSN, libres del VDVB endógeno fueron utilizados como sistema indicador en la prueba de virus neutralización. La Cepa "Singer" del VDVB obtenido comercialmente (NVS, AMES - IOWA, USA) fue utilizada como antígeno en la prueba de virus neutralización.

\section{Detección de anticuerpos contra el VDVB}

La detección de los anticuerpos en las muestras de leche fue mediante la prueba de ELISA indirecta según el manual de instrucciones de la casa comercial de procedencia de los kits de ELISA. Las densidades ópticas (DO) de las muestras fueron medidas en un espectrofotómetro con un filtro de $405 \mathrm{~nm}$. Según las indicaciones del kit utilizado, la prueba fue válida si la densidad óptica corregida (DOC) de la muestra de leche de referencia positiva era mayor que 1.0 y la DOC de la muestra de leche de referencia negativa fuese menor a 0.1 . Una muestra fue considerada positiva con una DOC dos veces mayor de la DOC de la muestra negativa y la muestra fue negativa con una DOC menor a 0.1 .

Los anticuerpos contra el VDVB en las muestras de suero $(n=65)$ fueron detectados mediante la prueba estándar de virus neutralización según el protocolo disponible en el Laboratorio de Virología de la FMV, UNMSM. Para evaluar la concordancia estadística entre la prueba de ELISA y virus neutralización se utilizó el índice de Kappa y McNemar de modo que la prueba de ELISA en leche pueda ser utilizada como 
un método alternativo ante el elevado costo y laboriosidad de la prueba de virus neutralización, ya que las inmunoglobulinas IgG están presentes tanto en leche como en suero.

\section{Mrumbre}

El 72.4\% (165/228) de las muestras de leche tuvieron anticuerpos contra el VDVB. El mayor porcentaje (86.3\%) de animales seroreactores fue detectado en la provincia de Concepción, seguido por los animales de la provincia de Jauja $(83.3 \%)$ y Huancayo (41.3\%) (Cuadro 1).

Los animales de todos los hatos muestreados presentaron anticuerpos contra el VDVB con prevalencias entre 9.4 a $100 \%$ tanto en hatos pequeños y medianos (Cuadro 2). En la Figura 1 se muestra los resultados obtenidos por la prueba de ELISA indirecta. En el Cuadro 3, se presentan los resultados de la detección de anticuerpos contra el VDVB en las muestras de suero $(n=65)$ y

Cuadro 1. Detección de anticuerpos contra el virus de la diarrea viral bovina en bovinos del valle del Mantaro mediante la prueba de ELISA indirecta en muestras de leche.

\begin{tabular}{lccccc}
\hline Provincia & Hatos, & Animales, & Animales & \multicolumn{2}{c}{ ELISA positivo } \\
\cline { 5 - 7 } & $\mathrm{n}$ & $\mathrm{n}$ & muestreados, $\mathrm{n}$ & $\mathrm{n}$ & $\%$ \\
\hline Concepción & 7 & 70 & 51 & 44 & 86.3 \\
Jauja & 7 & 146 & 114 & 95 & 83.3 \\
Huancayo & 4 & 102 & 63 & 26 & 41.3 \\
\hline Total & 18 & 318 & 228 & 165 & 72.4 \\
\hline
\end{tabular}

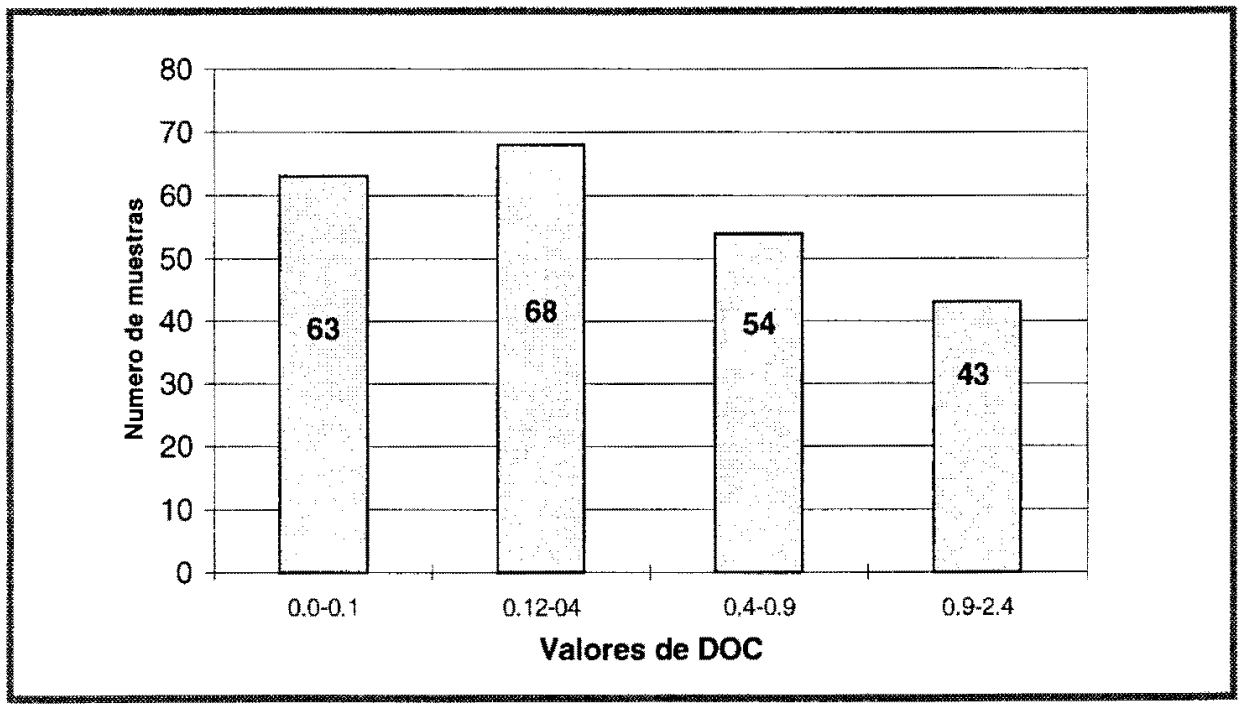

Figura 1. Densidades ópticas corregidas (DOC) obtenidas en las muestras de leche para la detección de anticuerpos contra el VDVB mediante la la prueba de ELISA indirecta $(n=228)$. 
su distribución según sus títulos mediante la prueba de virus neutralización y su comparación con los de la prueba de ELISA indirecta se muestra en el Cuadro 4.

\section{berstitn}

La presencia del VDVB en bovinos lecheros del valle del Mantaro con una prevalencia de $72.4 \%$ (156/228) corrobora la amplia distribụción de la infección viral en bovinos lecheros (Cuadro 1). Estos resultados no difieren de los efectuados en bovinos de otras cuencas lecheras del país (datos no publicados) ni los resultados en otros países como los Estados Unidos (65\%),
Reino Unido ( $62.5 \%$ ), países escandinavos (55 a $100 \%)$, Chile (50\%) etc., indicando que este virus esta ampliamente distribuido en la población bovina mundial (Houe, 1995). Sin embargo, a diferencia de lo que ocurre en otros países como Estados Unidos donde la enfermedad aguda y la enfermedad de las mucosas son frecuentemente reportados; en el Perú la DVB parecería ser principalmente de tipo subclínico posiblemente debido a la benignidad del clima y/o menor densidad de la población bovina

El nivel de prevalencia del VDVB en bovinos de las provincias de Concepción $(86.3 \%)$ y Jauja $(83.3 \%)$ fueron similares, la ligera diferencia con los resultados en los

Cuadro 2. Distribución de animales reactores al virus de la diarrea viral bovina en hatos estratificados por número de animales en producción.

\begin{tabular}{|c|c|c|c|c|c|}
\hline Provincia & $\begin{array}{l}\text { Promedio de animales } \\
\text { en producción }\end{array}$ & $\begin{array}{c}\text { Hatos, } \\
n\end{array}$ & $\begin{array}{c}\text { Animales } \\
\text { muestreados, } n\end{array}$ & $\begin{array}{c}\text { Reactores, } \\
\mathrm{n}\end{array}$ & $\%$ \\
\hline$\overline{\mathrm{C}}$ & 1 a 5 & 1 & 4 & 3 & 75.0 \\
\hline C & & 2 & 5 & 5 & 100.0 \\
\hline $\mathrm{H}$ & & 3 & 5 & 2 & 40.0 \\
\hline $\mathrm{J}$ & 6 a 10 & 1 & 6 & 2 & 33.3 \\
\hline $\mathrm{C}$ & & 2 & 6 & 3 & 50.0 \\
\hline $\mathrm{C}$ & & 3 & 6 & 5 & 83.3 \\
\hline $\mathrm{C}$ & & 4 & 7 & 7 & 100.0 \\
\hline J & & 5 & 8 & 3 & 37.5 \\
\hline $\mathrm{H}$ & & 6 & 8 & 8 & 100.0 \\
\hline $\mathrm{J}$ & & 7 & 9 & 5 & 55.5 \\
\hline$\overline{\mathrm{J}}$ & 11 a 20 & 1 & 12 & 7 & 58.5 \\
\hline $\mathrm{C}$ & & 2 & 15 & 13 & 86.7 \\
\hline $\mathrm{J}$ & & 3 & 16 & 16 & 100.0 \\
\hline $\mathrm{H}$ & & 4 & 17 & 16 & 94.1 \\
\hline $\mathrm{J}$ & & 5 & 18 & 14 & 77.8 \\
\hline $\mathrm{J}$ & 21 a más & 1 & 22 & 22 & 100.0 \\
\hline $\mathbf{J}$ & & 2 & 32 & 31 & 96.8 \\
\hline $\mathrm{H}$ & & 3 & 32 & 3 & 9.4 \\
\hline
\end{tabular}

$\mathrm{C}=$ Concepción, $\mathrm{H}=$ Huancayo, $\mathrm{J}=\mathrm{Jauja}$. 
animales de la provincia de Huancayo $(41.3 \%)$ podría deberse a un menor número de hatos muestreados (Cuadro 1). Anticuerpos contra el VDVB fueron detectados en todos los hatos muestreados con prevalencias de 9.4 a $100 \%$ (Cuadro 2), indicando diversos grados de actividad viral. Houe, (1995) señala que la prevalencia viral tiende a incrementarse en áreas con alta densidad de animales, especialmente en hatos de crianza intensiva o en lugares con severos cambios climáticos donde los animales son confinados durante el inviemo. En el valle del Mantaro los hatos en su mayoría están conformados por 5 a 10 animales y unos cuantos con más de 10 animales, además del tipo de crianza semiextensiva donde teóricamente el riesgo de transmisión viral debería ser mínima, la infección viral fue similar en pequeños, medianos y grandes hatos (Cuadro 2). Un factor importante que podría contribuir en la diseminación viral son las ferias ganaderas de la región como parte del sistema de comercialización del ganado del valle, pues en las ferias se reúnen animales de diversas edades, especies y condiciones sanitarias constituyendo potenciales medios de transmisión a los animales susceptibles y transmisiones interespecies que es frecuente entre los pestivirus (Nettleton et al., 1995).

Las distribuciones de las DOC de las muestras de leche variaron entre 0 a 2.4 (Fig. 1). Las densidades ópticas de las muestras leídas en el espectrofotómetro son directamente proporcional a la cantidad de proteínas presente en la muestra, en este sentido, las muestras con DOC entre 0.9 a 2.4 (Figura 1) significan altos títulos de anticuerpos como lo indica también los 25 animales con títulos $>$ a 1:256 en la prueba de virus neutralización (Cuadro 3). Estos altos títulos de anticuerpos pueden ser debido a infecciones recientes o desafíos continuos del virus ocasionando infecciones subclínicas en los

Cuadro 3. Detección de anticuerpos contra el virus de la diarrea viral bovina y la distribución de sus títulos mediante la prueba de virus neutralización en muestras de suero.

\begin{tabular}{|c|c|c|c|c|c|c|c|c|c|c|c|}
\hline \multirow{2}{*}{$\begin{array}{l}\text { Hatos/ } \\
\text { Prov. }\end{array}$} & \multirow{2}{*}{$\begin{array}{c}\text { Animales } \\
\text { muestreados, } n\end{array}$} & \multicolumn{2}{|c|}{ Muestras positivas } & \multicolumn{8}{|c|}{ Títulos de anticuerpos, $\mathrm{n}$} \\
\hline & & $\mathrm{n}$ & $\%$ & 2 & 4 & 8 & 16 & 32 & 64 & 128 & $>256$ \\
\hline $2 / \mathrm{J}$ & 9 & 8 & 89 & 0 & 0 & 0 & 1 & 2 & 1 & 2 & 2 \\
\hline $3 / \mathrm{J}$ & 5 & 5 & 100 & 0 & 0 & 0 & 0 & 0 & 0 & 1 & 4 \\
\hline $4 / \mathrm{J}$ & 3 & 2 & 67 & 0 & 0 & 0 & 0 & 0 & 1 & 0 & 1 \\
\hline $5 / \mathrm{J}$ & 1 & 0 & 0 & & & & & & & & \\
\hline $7 / \mathrm{J}$ & 18 & 18 & 100 & 0 & 0 & 0 & 2 & 4 & 4 & 4 & 4 \\
\hline $8 / \mathrm{C}$ & 3 & 3 & 100 & 0 & 0 & 0 & 0 & 0 & 1 & 0 & 2 \\
\hline $9 / \mathrm{C}$ & 4 & 4 & 100 & 0 & 0 & 0 & 0 & 0 & 1 & 0 & 3 \\
\hline $11 / \mathrm{C}$ & 3 & 2 & 67 & 0 & 0 & 0 & 0 & 0 & 1 & 0 & 1 \\
\hline $13 / \mathrm{C}$ & 2 & 2 & 100 & 0 & 0 & 0 & 0 & 0 & 0 & 1 & 1 \\
\hline $14 / \mathrm{C}$ & 3 & 3 & 100 & 0 & 0 & 0 & 0 & 0 & 0 & 0 & 3 \\
\hline $16 / \mathrm{H}$ & 6 & 1 & 17 & 0 & 0 & 0 & 0 & 0 & 0 & 0 & 1 \\
\hline $17 / \mathrm{H}$ & 2 & 1 & 50 & 0 & 0 & 0 & 0 & 0 & 0 & 0 & 1 \\
\hline $18 / \mathrm{H}$ & 6 & 4 & 67 & 0 & 0 & 0 & 0 & 0 & 1 & 1 & 2 \\
\hline Total & 65 & 53 & 81.5 & 0 & 0 & 0 & 3 & 6 & 10 & 9 & 25 \\
\hline
\end{tabular}

$\mathrm{J}=\mathrm{Jauja}, \mathrm{C}=$ Concepción, $\mathrm{H}=$ Huancayo 
animales adultos, pero podría estar propiciando infecciones de los tractos respiratorios y entéricos al dañar las células del sistema inmune especialmente del ternero.

La prueba de ELISA es una de las herramientas importantes para el diagnóstico y estudios epidemiológicos por su elevada sensibilidad, especificidad y su repetibilidad (Jacobson, 1998). El kit utilizado en el presente estudio tuvo $99.5 \mathrm{y}$ $97.7 \%$ de sensibilidad y especificidad para el diagnóstico del VDVB y otro aspecto significante es la utilización de la leche en lugar del suero. La muestras de leche son ricas en IgG y por tanto puede ser utilizada para detección y titulación de anticuerpos contra el VDVB u otros agentes infecciosos, su colección individual o de tanque facilita aun más si se desea detectar la infección del DVB en hatos, por lo que es muy útil para estudios epidemiológicos en gran escala (Niskanen et al., 1989).
En el Perú el ganadero andino es renuente a la toma de muestra de sangre de sus animales pero no lo es con la muestra de leche, significando esto una ventaja en la colección de muestras. En el presente estudio, con ambas pruebas, ELISA y virus neutralización, se tuvieron similares resultados en la detección de animales positivos y negativos. Sólo una muestra de leche positivo a anticuerpos por ELISA fue negativo por virus neutralización evidenciando la mayor sensibilidad de la prueba de ELISA (Cuadro 4). Siendo la prueba de virus neutralización costosa, laboriosa y que requiere muestras de suero y existiendo una perfecta concordancia estadística con la prueba de ELISA en leche, se recomienda el uso de la leche para estudios seroepidemiológicos no solamente de la DVB sino también, de otras enfermedades prevalentes como la brucelosis.

Cuadro 4. Comparación de los resultados de las pruebas de ELISA indirecta en muestras de leche y virus neutralización en muestras de suero en la detección de anticuerpos contra el VDVB.

\begin{tabular}{|c|c|c|c|c|}
\hline & & \multicolumn{3}{|c|}{ Prueba de virus neutralización } \\
\hline & & $\begin{array}{c}\text { Animales } \\
\text { positivos, } n\end{array}$ & $\begin{array}{c}\text { Animales } \\
\text { negativos, } \mathrm{n}\end{array}$ & $\begin{array}{c}\text { Total, } \\
\mathrm{n}\end{array}$ \\
\hline \multirow{3}{*}{ 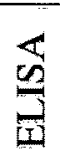 } & Animales positivos, $n$ & 52 & 1 & 53 \\
\hline & Animales negativos, $\mathrm{n}$ & 0 & 12 & 12 \\
\hline & Total & 52 & 13 & 65 \\
\hline
\end{tabular}

\section{Miteritura oitath}

1. Bezek, D.M. 1995. Bovine virus diarthea virus infection: individual and herd diagnosis, Compendium on Continuing Education. 17(8):57-64

2. Brownlie, J.; L.B, Hooper; I.
Thompson y M.E. Collins. 1998. Maternal recognition of foetal infection with bovine virus diarrhoea virus (BVDV) - the bovine pestivirus. Clin Diagn Virol. 10: 141-150.

3. Fernández-Baca, E. y C. Bojórquez. 1995. Diagnóstico de la producción 
lechera en el valle del Mantaro: 2 Producción de leche. Rev Inv Pec IVITA (Perú). 7(2): 97-106.

4. Fredriksen, B.; C. McL. Press; T. Loken y S.A. Odegaard. 1999. Distribution of viral antigen in uterus, placenta and foetus of cattle persistently infected with bovine virus diarthoea virus. Vet Microbiol. 64:109-122.

5. Fritzemeier, J.; L. Haas; E. Liebler; V. Moennig y I. Greiser-Wilke. 1997. The development of early vs. Late onset mucosal disease is a consequence of two different pathogenic mechanisms. Arch virol. 142: 1335-1350.

6. Houe, H. 1995. Epidemiology of bovine viral diarrhea virus. Vet Clin of North Am. Food Animal Prectice. 11(3):521547.

7. Jacobson, R.H. 1998. Validation os serological assays for diagnosis of infectiuos diseases. Rev Sci Tech Off Int Epiz. 17 (2): 469-486.

8. Li.L.; H.D. Lehmkuhl y M.L. Kaeberle. 1998. Synergistic effect of bovine respiratory syncitial virus and noncytopathic bovine viral diarrhea virus infection in selected bovine alveolar macrophage functions. Can J Vet Res. 63:41-48.

9. Marshall, D.J.; A.P. Gregory; C.A. Kuszynsky; K.M. Eskridge y C.L. Kelling. 1994. Flow cytometric analysis of limphocyte subsets in periferal blood and limphoid tissues of gnotobiotic calves during primary acute postnatal infection of bovine viral diarrhea virus. Viral Immunol. 7(3):141-149.

10. Nettleton, P.F y G. Entrican. 1995. Ruminant Pestivirus. Br Vet J. 151: 515642.
11. Niskanen, R.; S. Alenius; S. Larsson $y$ N. Juntti. 1989. Evaluation of an enzyme-linked immunosorbent assay for detection of antibodies to bovine virus diarrhoea virus in milk. $J$ Vet Med B 36:113-118

12. Potgieter, L.N.D. 1997. Bovine respiratory tract disease caused by bovine viral diarrhea virus. Vet Clin of North Am. Food Animal Practice. 13 (3): 471-481.

13. Rivera, H.; A. Manchego; N. Sandoval; A. Vargas; A. Araujo; $A$. González y R. Rosadio. 1993. Aborto infecciosos en bovinos lecheros del valle de Lima. Rev Inv Pec IVITA (Perú). 6 (1): 31-37.

14. Rivera, H.; A. Manchego; N. Sandoval; C. Morales y E. Flores. 1994. Complejo respiratorio bovino en terneros del valle de Lima. Rev Inv Pec IVITA (Perú). 7 (1): 35-38.

15. Schreiber, P., F. Dubois, F. Dreze, N. Lacroix, B. Limbourg y Ph. Coppe. 1999. Prevalence of bovine virus diarrhoea vinus infection in Belgian white blue cattle in southern Belgium. Vet Quart. 21(1): 28-32.

16. Zanabria V. 1999. Etiología del sindrome neumónico en vacunos de engorde en Lima. Tesis Magister Fac Med Vet. Uni. Mayor de San Marcos. $70 \mathrm{p}$.

17. Wengler, G.; W.D. Bradley; M.S. Collet; F.X. Heinz; W.R. Schlesinger y J.H. Strauss. 1995. Flaviviridae. In: Virus taxonomy. Sixth Report on the International Committee on taxonomy of viruses. Vienna and New york: Springer Verlag. p415-427. 